\title{
Synergistic antifungal evaluation of over- the-counter antifungal creams with turmeric essential oil or Aloe vera gel against pathogenic fungi
}

\author{
Clement Olusola Ogidi ${ }^{*}$ (D), Ayokunbi Elizabeth Ojo², Oluwatayo Benjamin Ajayi-Moses², \\ Oluwatoyin Modupe Aladejana ${ }^{3}$, Oluwakemi Abike Thonda ${ }^{3}$ and Bamidele Juliet Akinyele ${ }^{2}$
}

\begin{abstract}
Background: The frequent incidence of fungal infection and widespread of antibiotic resistance are emergent concerns in public health. Hence, there is a need to harness the potential of natural bioactive compounds from plant towards treatment of fungal infection. Combination effect of antibiotic creams with natural products from plants is prospective strategy to produce new antifungal agent. This study therefore, revealed antifungal effect of combined Antifungal Creams (AFCs) with Turmeric Essential Oil (TEO) or Aloe vera Gel (AVG).
\end{abstract}

Methods: Phytochemicals and bioactive compounds in TEO and AVG were revealed using GC-MS. Bioactive compounds in plant extracts were compared to known compounds in database library of National Institute of Standards and Technology (U.S.). Antifungal activity and synergistic effect of AFCs with TEO or AVG were carried out using agar well diffusion method.

Results: Phenol, flavonoids, saponins, alkaloids, steroids, terpenoids and cardiac glycosides were present in TEO and AVG. GCMS revealed thirty-six (36) and eighteen (18) bioactive compounds in TEO and AVG, respectively. AFCs displayed zones of inhibition with values ranged from 5.0 to $14.3 \mathrm{~mm}$, TEO was 5.0 to $11.0 \mathrm{~mm}$ and AVG was 8.0 to $11.7 \mathrm{~mm}$ against tested fungi. Minimum Inhibitory Concentration (MIC) by AFCs, TEO and AVG ranged from 1.25 to $10.0 \mathrm{mg} / \mathrm{ml}$. Combinatory effects of AFCs with TEO or AVG revealed synergistic and indifferent properties.

Conclusion: Development of novel products using bioactive ingredients from plants with commercially available AFCs will serve as potential alternative therapy to cure dermatological infections with no side effects.

Keywords: Dermatophytes, -azole, Terbinafine, Curcuma longa rhizomes, Cosmeceutical, GC-MS

\section{Background}

Mycotic diseases are causing significant morbidity and now seen as a serious concern to public health $[1,2]$. The spread of fungal diseases is increasing by overuse of broad-spectrum antibiotics, which lessening non-

\footnotetext{
* Correspondence: clementogidi@yahoo.com

'Biotechnology Unit, Department of Biological Sciences, Kings University, PMB 555, Odeomu, Nigeria

Full list of author information is available at the end of the article
}

pathogenic bacterial population that check the growth of fungi through competition [3]. Antifungal drugs play active roles in the treatment of some fungal infections but their misuse always made the fungal infection worsen. Superficial and subcutaneous fungal infections are very dangerous if not promptly and properly treated with appropriate drugs. The erroneous use of antifungal drugs has contributed to frequent resistance experience over the past decades [4]. In addition, most antifungal drugs

(c) The Author(s). 2021 Open Access This article is licensed under a Creative Commons Attribution 4.0 International License, which permits use, sharing, adaptation, distribution and reproduction in any medium or format, as long as you give appropriate credit to the original author(s) and the source, provide a link to the Creative Commons licence, and indicate if changes were made. The images or other third party material in this article are included in the article's Creative Commons licence, unless indicated otherwise in a credit line to the material. If material is not included in the article's Creative Commons licence and your intended use is not permitted by statutory regulation or exceeds the permitted use, you will need to obtain permission directly from the copyright holder. To view a copy of this licence, visit http://creativecommons.org/licenses/by/4.0/. The Creative Commons Public Domain Dedication waiver (http://creativecommons.org/publicdomain/zero/1.0/) applies to the data made available in this article, unless otherwise stated in a credit line to the data. 
currently available to treat fungal infections have serious drawbacks, which include low concentration of active ingredients, itching on the skin due to chemical composition, development of fungi resistance and toxic side effects [5]. Conventional formulation of creams, powder, gels to treat skin or deep seated fungal infections still have various side-effects like burning, redness and swelling on the application site [6]. Beside different side effects committed to commercially available antifungal drugs, these days, multiple drug resistance is fast rising worldwide and efficacy of single antibiotic against resistant microorganisms is abating. The continuous therapeutic failure as a result of multi-drug resistance by pathogenic fungi is urgently demanding for innovative complementary approach towards production of novel, alternative and effective antimicrobial drugs. Invention of antifungal drugs with different drug delivery systems like liposomes, niosomes, ethosomes, microemulsions, microsponge, nanoparticles are now embraced as treatment option for fungal infection in order to achieve clinical efficacy $[6,7]$. The increasing therapeutic potentials of drug combination has been found more efficacious than single antifungal agent aimed at a single target [8].

To overcome the drawbacks of conventional therapy and to produce antifungal agents with dose efficient, a blueprint for development of effective antifungal drugs or creams from natural herbs is now an element of consensus among researchers, medical practitioners and pharmaceutical companies [9]. To enhance efficacies of antibiotics (creams or drugs) and to minimize their side effects, combinatory effect of commercial antifungal drugs with natural products will demonstrate a huge success in treating fungal infections. Antifungal drugs with live lactic acid bacteria (probiotics) were designed to protect, restore the natural balance in the vagina and help to fight yeast infection without side effects [10]. Globally, combination and synergistic interaction of antimicrobial agents with multiple herbs formulation of different natural bioactive compounds are the main therapy to cure some medical challenges [11]. Antifungal combination therapy is trending with veracity in the fields of infectious diseases and medical mycology [12]. The combination and synergistic effects of commercial antifungal drugs with natural bioactive compounds from plants will be a complementary and alternative approach to combat reoccurrence incidences of fungal infection.

Medicinal plants are imperious sources of treasurable secondary metabolites and thus, contribute to availability of natural drugs in global markets [13]. Turmeric; Curcuma longa belong to ginger family; Zingiberaceae. Turmeric powder from dried ground rhizomes of $C$. longa possess culinary uses, act as natural product with analgesic, antibacterial, antifungal, anti-inflammatory, antioxidant, and digestive properties. Hence, biological activities of turmeric, its health promoting effects and disease prevention have attracted several applications in pharmaceutical, food and biotechnological industries [14]. Aloe vera, is another medicinal plant with immense bioactive compounds allied with some pharmacological properties like wound healing, antifungal activity, hypoglycemic or antidiabetic effects, anti-inflammatory, anticancer, immunomodulatory and gastroprotective [15]. The therapeutic potentials of $A$. vera in phytomedicine indicate its several uses in pharmaceutical and cosmetic industries [16]. Natural products in plants act as reservoirs of novel bioactive compounds and as excellent source of drug discovery with divers' biopharmaceutical applications [17], hence, biologically active compounds in medicinal plants can be exploited and incorporated in AFCs, which will be a newsworthy option towards new prototype antifungal agents. This study therefore, revealed synergistic antifungal potential of over-thecounter AFCs with TEO or AVG against clinically important pathogenic fungi.

\section{Methods \\ Sample collection}

Turmeric was collected from a farmland in Isarun Village, Ifedore Local Government Area, Ondo State. The rhizomes were washed with distilled water before they were cut into smaller pieces. Aloe vera was obtained from a farmland in Aule, Akure South Local Government Area, Ondo state. C. longa rhizomes and Aloe vera were authenticated at the Department of Crop, Soil and Pest Management, The Federal University of Technology, Akure and was deposited in the herbarium of the same Department.

\section{Source of antifungal creams (AFCs)}

The commercially available AFCs namely; clotrimazole (1\%), fluconazole $(0.5 \%)$, ketoconazole $(2 \%)$ and terbinafine $(1 \%)$ were purchased. These AFCs were certified by National Agency for Food and Drug Administration and Control (NAFDAC), a federal agency under the Federal Ministry of Health; responsible for regulation and control of importation, exportation, advertisement, distribution, sale and use of food, drugs, cosmetics, medical devices, chemicals and packaged water in Nigeria.

\section{Collection of tested fungi}

The tested fungal isolates namely: Candida tropicalis (ATCC 66029) was obtained from Nigeria Institute of Medical Research, Lagos. Candida albicans, Penicillium notatum, Aspergillus fumigatus, A. niger, A. flavus, Trichophyton rubrum, Trichophyton violceum and Trichophyton mentagrophytes were collected from Department of Medical Microbiology Laboratory, Federal Medical Centre, Ido-Ekiti, Nigeria. 


\section{Extraction of TEO and AVG}

Essential oil was extracted from the turmeric rhizomes by the process of steam distillation using Clevenger apparatus [18]. Fresh rhizome (100 g) of turmeric was boiled with $500 \mathrm{ml}$ of distilled water in a Clevenger apparatus until oil distillation ceased after $5 \mathrm{~h}$. The volume of essential oil was determined from a calibrated trap. The essential oil in the distillate were dried over anhydrous $\mathrm{Na}_{2} \mathrm{SO}_{4}$ and kept in the freezer. A. vera leaf was cleaned with ethanol, dissected and the gel; jelly-like substance found in the inner part of the $A$. vera leaf was aseptically collected into sterile tubes.

\section{Determination of phytochemicals and bioactive compounds in TEO and AVG}

Qualitative and quantitative phytochemicals in TEO and AVG were determined using the standard methods. Briefly, total phenolic and flavonoid contents of extracts was determined according to the method of Sofowora [19]. The methods stated by Harborne [20] and Trease and Evan [21] were used to determined alkaloids, saponins, tannins, steroid, tepernoids and cardiac glycoside. The method described by Soladoye [22] was used to determine the anthraquinone content.

The bioactive compounds in the TEO and AVG were identified with the aid of gas chromatography- mass spectrometry (QP2010 plus Shimadzu, Japan), which was equipped with a split injector and an ion - trap mass spectrometer detector together with a fused - silica capillary column having a thickness of $1.00 \mu \mathrm{m}$, dimensions of $20 \mathrm{~m} \times 0.22 \mathrm{~mm}$ and temperature limits of $60^{\circ} \mathrm{C}$ to $325^{\circ} \mathrm{C}$. The column temperature was programmed between $60^{\circ} \mathrm{C}$ and $250^{\circ} \mathrm{C}$ at a rate of $0.5 \mathrm{~m} / \mathrm{s}$ with pressure of $100.2 \mathrm{Kpa}$. The temperature of the injector and detector were at $250{ }^{\circ} \mathrm{C}$ and $200{ }^{\circ} \mathrm{C}$ respectively. Helium gas was used as a carrier gas at flow rate of $0.46 \mathrm{~m} / \mathrm{s}$. The MS analysis was done based on comparative retention times, mass and peaks of the chemical compounds using the computer-aided matching of unknown mass spectra of compounds with the known compounds stored in the software database library from the National Institute of Standards and Technology (NIST), Washington, USA, having more than 62,000 patterns as the reference database. The name, molecular weight and the structure of the components of the tested materials were ascertained with database library from the NIST, Washington, USA.

\section{Antifungal activities of AFCs, TEO and AVG}

The antifungal assay was carried out using the agar well diffusion method described by CLSI [23, 24]. Suspensions of fungi $\left(1.0 \times 10^{5} \mathrm{sfu} / \mathrm{ml}\right)$ was adjusted with the aid of spectrophotometer (UNICO S-1100 RS) to 0.5
McFarland standard. Dimethyl sulfoxide (DMSO 2\% v/v) was used to reconstitute since most of AFCs and plant extracts (TEO and AVG) were not soluble in sterile distilled water. The concentration of AFCs, TEO and AVG were reconstituted to $10.0 \mathrm{mg} / \mathrm{ml}$. Plant extract was sterilized using a Millipore membrane filter $(0.22 \mu \mathrm{m})$. The sterility of TEO and AVG were confirmed after Millipore filtration, by introducing $0.1 \mathrm{ml}$ of supposed sterile extract into sterilized nutrient agar and potato dextrose agar. Each labelled plate was seeded with tested fungi by means of sterile swab stick rolled on potato dextrose agar. Sterile cork borer was used to make well $(6 \mathrm{~mm})$ in the Petri dishes. Aliquots of TEO, AVG and AFCs $(50 \mu \mathrm{l})$ were dropped in each well. DMSO solution was used as the negative control. The plates were incubated at $26^{\circ} \mathrm{C}$ for $48 \mathrm{~h}$. The zones of inhibition around well were measured in millimeter $(\mathrm{mm})$. For synergism activity, concentration of each AFCs, TEO and AVG was adjusted to $3.0 \mathrm{mg} / \mathrm{ml}$.

\section{Determination of minimum inhibitory and fractional inhibitory concentration index (FICi)}

The minimum inhibitory concentration was determined by using method described by CLSI $[23,24]$.

The varying concentrations of $1.25,2.5,5.0$, and 10.0 $\mathrm{mg} / \mathrm{ml}$ for AFCs, TEO and AVG were prepared and incorporated into a set of sterile tubes. Each test tube was inoculated with $0.1 \mathrm{ml}$ of standardized fungal inoculum and incubated at $26^{\circ} \mathrm{C}$ for $48 \mathrm{~h}$. The MIC were recorded as the lowest concentration to prevent growth of macroscopically visible colonies on plates, while there was visible growth on plates without AFCs, TEO and AVG. To determine MIC of combined AFC with TEO or AVG, varying concentrations of $1.0-3.0 \mathrm{mg} / \mathrm{ml}$ was used. The synergism, indifference, and antagonism of combined AFC with TEO or AVG were screened on the studied pathogenic fungi. MICs were transformed into Fractional Inhibitory Concentration (FIC) to determine the interaction of two samples in the following manner:

FIC of AFC = MIC of AFC in presence of TEO/MIC of $\mathrm{AFC}$

FIC of TEO $=$ MIC of TEO in presence of AFC /MIC of TEO

or

FIC of AFC $=$ MIC of AFC in presence of AVG /MIC of AFC

FIC of AVG = MIC of AVG in presence of AFC /MIC of AVG

Fractional Inhibitory Concentration index (FICi) for each sample was calculated from FIC values as follows:

$\mathrm{FICi}=\mathrm{FIC}$ of $\mathrm{AFC}+\mathrm{FIC}$ of TEO

or

$\mathrm{FICi}=\mathrm{FIC}$ of $\mathrm{AFC}+\mathrm{FIC}$ of AVG. 
The FICi was interpreted as: synergistic when FICi $\leq 0.5$; indifferent when FICi was $0.5-4.0$ and antagonistic when FICi $\geq 4.0$ [25].

\section{Statistical analysis}

Experimental studies were carried out in replicates $(n=3)$. Data obtained were subjected to one-way analysis of variance (ANOVA) using Statistical Package for Social Sciences (SPSS) version 20, USA. Results obtained were reported as mean \pm standard deviation (SD). Values were compared by Duncan's new multiple range test (MRT) and differences were considered significant when $P<0.05$.

\section{Results}

Phytochemical and bioactive compounds in TEO and AVG as revealed by GC-MS

The quantity of phytochemicals of TEO and AVG was revealed in Fig. 1. Phytochemical such as phenol, flavonoids, saponins, alkaloids, steroids, terpenoids and cardiac glycosides were present in TEO and AVG. while anthraquinones and tannins was present only in AVG. Phenol was present with values of $2.9 \mathrm{mg} / 100 \mathrm{~g}$ and 5.1 $\mathrm{mg} / 100 \mathrm{~g}$ in TEO and AVG, respectively. Alkaloid in TEO and AVG were not significantly different $(p=0.05)$ with value of $2.3 \mathrm{mg} / 100 \mathrm{~g}$ and $2.1 \mathrm{mg} / 100 \mathrm{~g}$. Anthraquinones and tannins in AVG was $3.5 \mathrm{mg} / 100 \mathrm{~g}$ and 2.3 $\mathrm{mg} / 100 \mathrm{~g}$, respectively. Cardiac glycoside has the least values of $0.30 \mathrm{mg} / 100 \mathrm{~g}$ in TEO and $0.48 \mathrm{mg} / 100 \mathrm{~g}$ in AVG. Figures 2 and 3 show chromatogram of TEO and AVG with peaks for various bioactive constituents. The peaks were shown for 36 and 18 bioactive compounds in TEO and AVG, respectively. Tables 1 and 2 show the presence of bioactive compounds in TEO and AVG, respectively identified with GC MS. Z-citral was the major compound in the TEO (14.02\%), while Z-9-Tetradecenol (24.99\%) was the most abundant compound in AVG. Bioactive compounds such as $\alpha$-pinene, camphene, linalool, borneol, p-menth-1-en-8-ol, zingiberene, farnesene, farnesol and others were found in TEO (Table 1). In AVG, cis oleic acid, dioctyl adipraate, glycerin 1,3-distearate, arachidic acid methyl ester, dipentene diepox, z9-tetradecenol and others (Table 2).

Inhibitory potentials and synergistic antifungal efficacy of AFCs with TEO or AVG against pathogenic fungi

The zones of inhibition $(\mathrm{mm})$ reflecting the antifungal efficacy of AFCs, TEO and AVG were reported in Table 3. AFCs namely; clotrimazole, fluconazole, ketoconazole and terbinafine displayed zones of inhibition against tested fungi with values ranged from 5.0 to 11.6 $\mathrm{mm}, 5.0$ to $11.3 \mathrm{~mm}, 5.0$ to $11.3 \mathrm{~mm}$ and 8.0 to $14.3 \mathrm{~mm}$, respectively. TEO have inhibitory zones of 5.0 to 11.0 $\mathrm{mm}$, while AVG have 8.0 to $11.7 \mathrm{~mm}$ against tested fungi. Varying zones of inhibition indicated antifungal activity of combined AFCs with TEO or AVG as shown

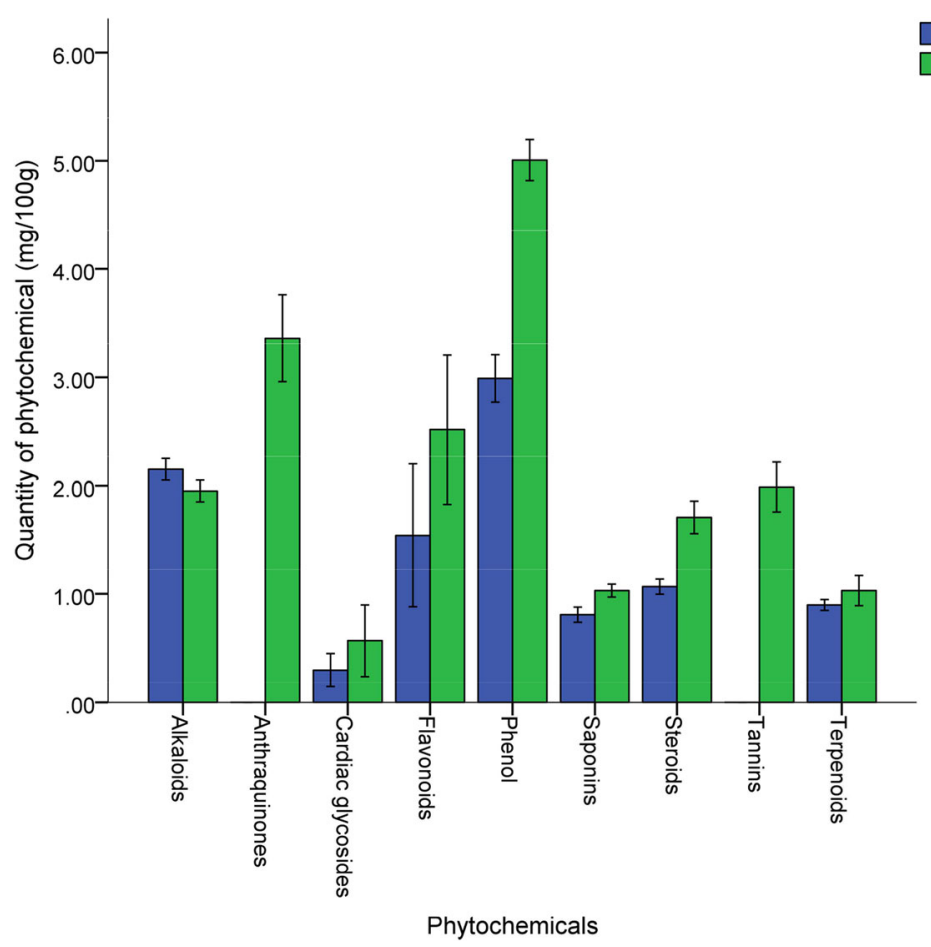

Fig. 1 Quantitative constituents (mg/100 g) of phytochemicals in TEO and AVG. Error bar is SD 


\section{SAMPLE-TURNERIC ESSENTIAL OIL}

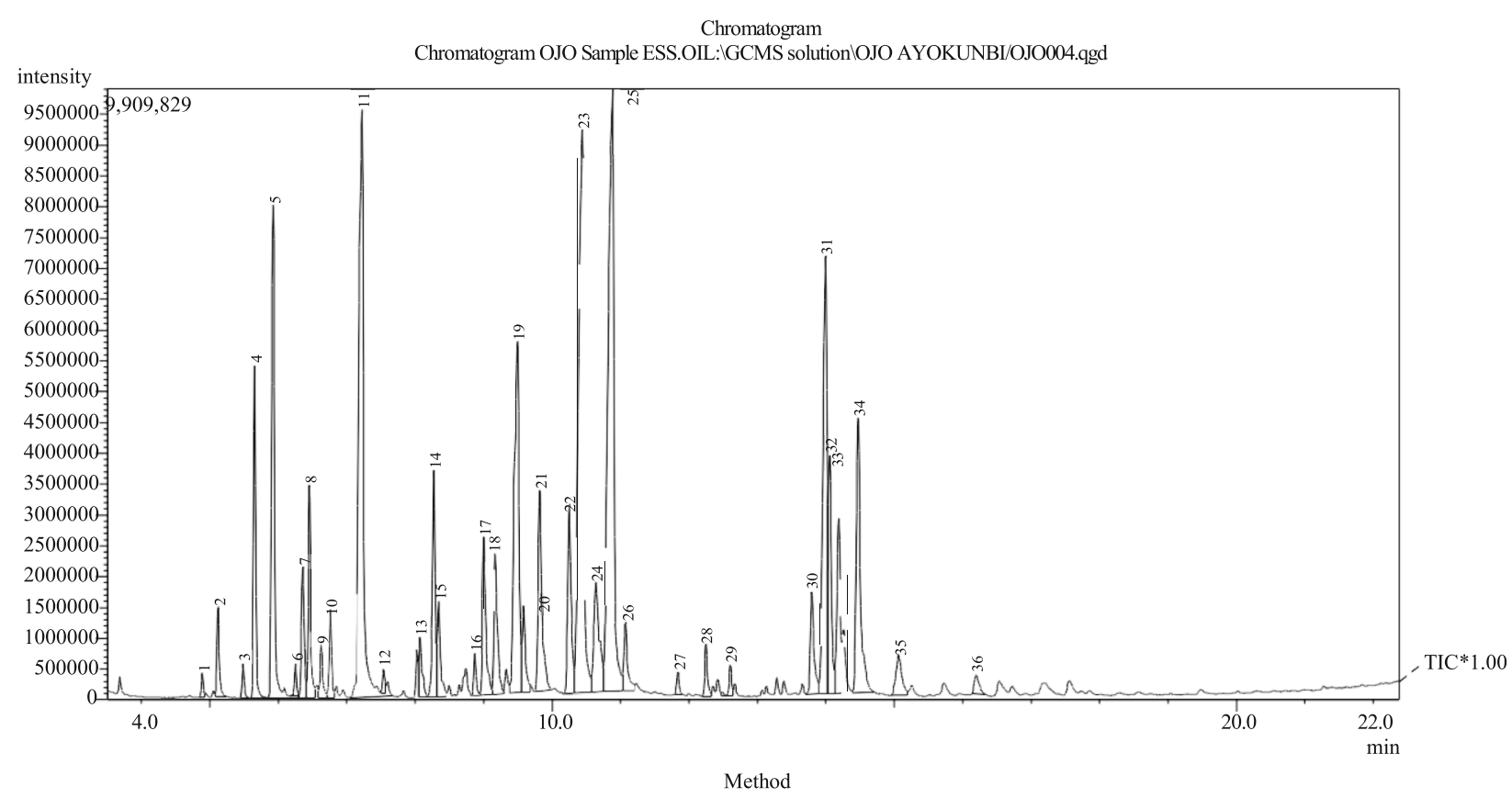

Fig. 2 Chromatogram of TEO with peaks for various bioactive constituents

in Table 4. Combinatory effect of AFCs with TEO or AVG showed better inhibitory zones against fungi. Ketoconazole + TEO, terbinafine + TEO, fluconazole + AVG and terbinafine + AVG have similar $(p<0.05)$ inhibitory effects against $C$. tropicalis (ATCC 66029). Terbinafine
+ AVG displayed the highest $(p<0.05)$ zones of inhibition of $12.7 \mathrm{~mm}$ and $13.6 \mathrm{~mm}$ against $C$. albicans and Penicillium notatum, respectively. Zones of inhibition displayed by each AFC combined with AVG against $A$. fumigatus were not significantly different when $p<0.05$.

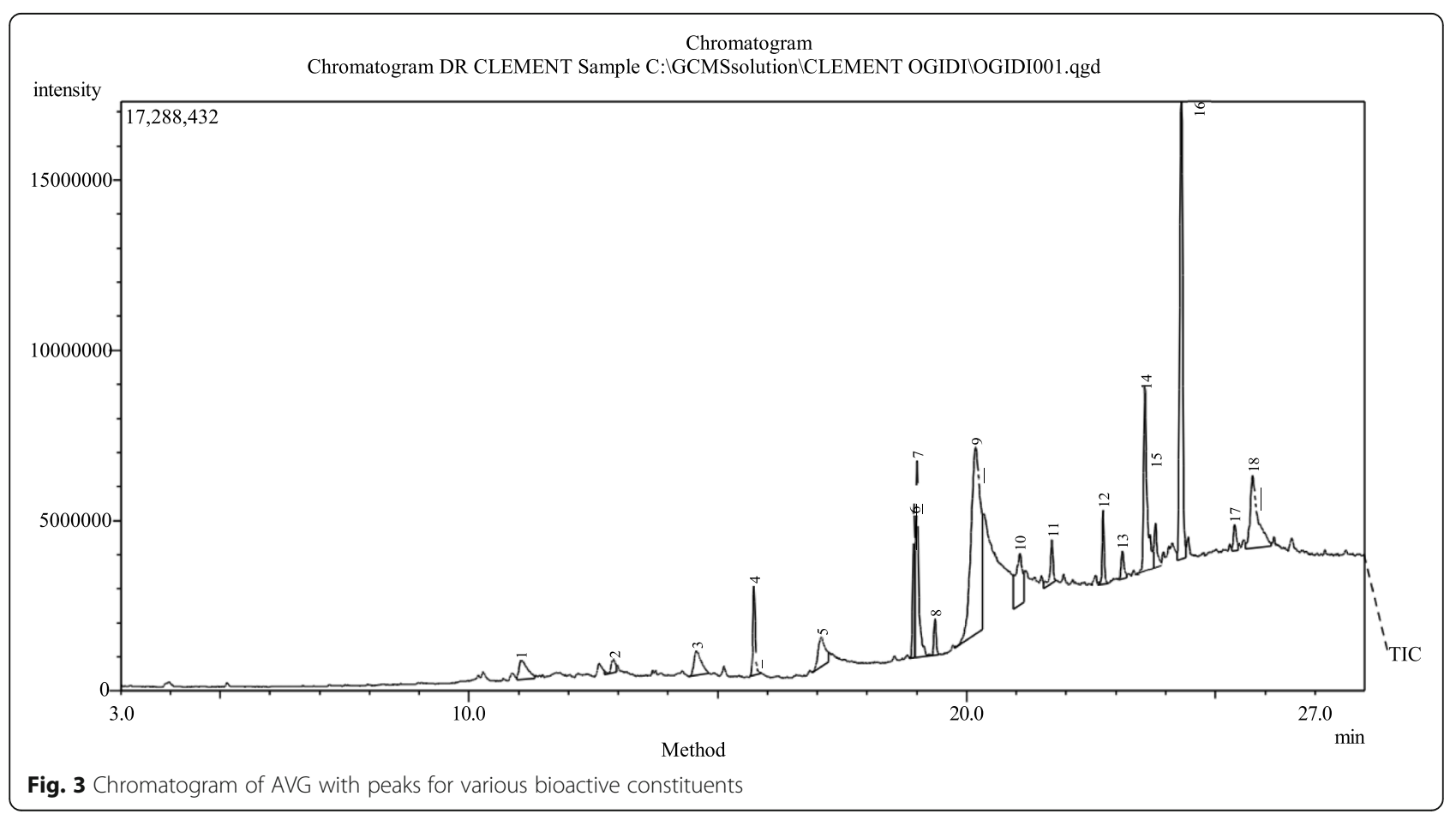


Table 1 Main component and the relative contents of TEO as revealed by GCMS

\begin{tabular}{|c|c|c|c|c|c|}
\hline Peaks & Retention time & Area $\%$ & Bioactive compounds & Molecular formula & Molecular weight \\
\hline 1 & 4.886 & 0.19 & n-pentyl methyl ketone & $\mathrm{C}_{7} \mathrm{H}_{14} \mathrm{O}$ & 114 \\
\hline 2 & 5.115 & 0.85 & Amyl methyl carbinol & $\mathrm{C}_{7} \mathrm{H}_{16} \mathrm{O}$ & 116 \\
\hline 3 & 5.483 & 0.30 & Tricyclene & $\mathrm{C}_{10} \mathrm{H}_{16}$ & 136 \\
\hline 4 & 5.652 & 3.01 & a -pinene & $\mathrm{C}_{10} \mathrm{H}_{16}$ & 136 \\
\hline 5 & 5.924 & 6.25 & Camphene & $\mathrm{C}_{10} \mathrm{H}_{16}$ & 136 \\
\hline 6 & 6.251 & 0.25 & Sabinene & $\mathrm{C}_{10} \mathrm{H}_{16}$ & 136 \\
\hline 7 & 6.355 & 1.55 & 6-Methyl-5-hepten-2-one & $\mathrm{C}_{8} \mathrm{H}_{14} \mathrm{O}$ & 126 \\
\hline 8 & 6.452 & 2.01 & $\beta$-Myrcene & $\mathrm{C}_{10} \mathrm{H}_{16}$ & 136 \\
\hline 9 & 6.625 & 0.55 & Caprylaldehyde & $\mathrm{C}_{8} \mathrm{H}_{16} \mathrm{O}$ & 128 \\
\hline 10 & 6.756 & 0.82 & a-Phellandrene & $\mathrm{C}_{10} \mathrm{H}_{16}$ & 136 \\
\hline 11 & 7.222 & 11.41 & cis-.beta.-Terpineol & $\mathrm{C}_{10} \mathrm{H}_{18} \mathrm{O}$ & 154 \\
\hline 12 & 7.535 & 0.23 & (E)-2-Octenal & $\mathrm{C}_{8} \mathrm{H}_{14} \mathrm{O}$ & 126 \\
\hline 13 & 8.070 & 0.76 & 2-Carene & $\mathrm{C}_{10} \mathrm{H}_{16}$ & 136 \\
\hline 14 & 8.272 & 2.57 & Linalol & $\mathrm{C}_{10} \mathrm{H}_{18} \mathrm{O}$ & 154 \\
\hline 15 & 8.341 & 1.21 & d-Verbenol & $\mathrm{C}_{10} \mathrm{H}_{16} \mathrm{O}$ & 152 \\
\hline 16 & 8.871 & 0.41 & 2-Methyl-6-methylene 2-octene & $\mathrm{C}_{10} \mathrm{H}_{18}$ & 138 \\
\hline 17 & 9.001 & 2.18 & Citronellal & $\mathrm{C}_{10} \mathrm{H}_{18} \mathrm{O}$ & 154 \\
\hline 18 & 9.167 & 1.90 & Artemiseole & $\mathrm{C}_{10} \mathrm{H}_{16} \mathrm{O}$ & 152 \\
\hline 19 & 9.494 & 6.59 & Borneol & $\mathrm{C}_{10} \mathrm{H}_{18} \mathrm{O}$ & 154 \\
\hline 20 & 9.584 & 1.09 & 1-Terpinen-4-ol & $\mathrm{C}_{10} \mathrm{H}_{18} \mathrm{O}$ & 154 \\
\hline 21 & 9.818 & 3.10 & p-menth-1-en-8-ol & $\mathrm{C}_{10} \mathrm{H}_{18} \mathrm{O}$ & 154 \\
\hline 22 & 10.248 & 2.65 & $\beta$-Citronellol & $\mathrm{C}_{10} \mathrm{H}_{20} \mathrm{O}$ & 156 \\
\hline 23 & 10.440 & 11.94 & cis,trans-Citral & $\mathrm{C}_{10} \mathrm{H}_{16} \mathrm{O}$ & 152 \\
\hline 24 & 10.635 & 2.48 & trans-Geraniol & $\mathrm{C}_{10} \mathrm{H}_{18} \mathrm{O}$ & 154 \\
\hline 25 & 10.881 & 14.02 & Z-Citral & $\mathrm{C}_{10} \mathrm{H}_{16} \mathrm{O}$ & 152 \\
\hline 26 & 11.072 & 1.06 & Methyl nonyl ketone & $\mathrm{C}_{10} \mathrm{H}_{18}$ & 138 \\
\hline 27 & 11.836 & 0.21 & (6E)-2,6-Dimethyl-2,6-octadiene & $\mathrm{C}_{10} \mathrm{H}_{18}$ & 138 \\
\hline 28 & 12.247 & 0.57 & Geraniol acetate & $\mathrm{C}_{12} \mathrm{H}_{20} \mathrm{O}_{2}$ & 172 \\
\hline 29 & 12.603 & 0.34 & 2,4-Diisopropenyl-1-methyl-1-vinylcyclohexane & $\mathrm{C}_{15} \mathrm{H}_{24}$ & 204 \\
\hline 30 & 13.794 & 1.54 & a-Curcumene & $\mathrm{C}_{15} \mathrm{H}_{22}$ & 202 \\
\hline 31 & 13.998 & 7.27 & Zingiberene & $\mathrm{C}_{15} \mathrm{H}_{24}$ & 204 \\
\hline 32 & 14.056 & 2.68 & Farnesene & $\mathrm{C}_{15} \mathrm{H}_{24}$ & 204 \\
\hline 33 & 14.189 & 2.26 & (Z)-.beta.-Farnesene & $\mathrm{C}_{15} \mathrm{H}_{24}$ & 204 \\
\hline 34 & 14.472 & 4.47 & $\beta$-Sesquiphellandrene & $\mathrm{C}_{15} \mathrm{H}_{24}$ & 204 \\
\hline 35 & 15.064 & 0.92 & D-nerolidol & $\mathrm{C}_{15} \mathrm{H}_{26} \mathrm{O}$ & 222 \\
\hline 36 & 16.196 & 0.37 & (2E,6E)-Farnesol & $\mathrm{C}_{15} \mathrm{H}_{26} \mathrm{O}$ & 222 \\
\hline
\end{tabular}

Inhibitory action of each AFC combined with TEO against A. fumigatus were also similar. Ketoconazole + AVG and terbinafine + AVG respectively have similar inhibitory zones of $12.7 \mathrm{~mm}$ and $13.7 \mathrm{~mm}$ against $T$. mentagrophytes.

Table 5 shows minimum inhibitory concentration of AFCs, TEO and AVG against fungi. AVG displayed lower range of MIC values (1.25 to $5.0 \mathrm{mg} / \mathrm{ml}$ ), while other were within 1.25 to $10 \mathrm{mg} / \mathrm{ml}$. The MIC obtained for combined AFCs with TEO or AVG was shown in Table 6. Combination of clotrimazole + AVG displayed lower MIC value of 1.0 to $2.0 \mathrm{mg} / \mathrm{ml}$ against tested fungi. The MICs of fluconazole + AVG, ketoconazole + AVG, and terbinafine + AVG were within 1.0 to $2.5 \mathrm{mg} / \mathrm{ml}$ against tested fungi. Table 7 shows FIC, FIC indices (FICi) as well as their 
Table 2 Main component and the relative contents of AVG as revealed by GCMS

\begin{tabular}{llllll}
\hline Peaks & Retention time & Area $\%$ & Bioactive compounds & Molecular formula & Molecular weight (g/mol) \\
\hline 1 & 11.049 & 2.18 & 3-Hydroxybenzhydrazide & $\mathrm{C}_{7} \mathrm{H}_{8} \mathrm{~N}_{2} \mathrm{O}_{2}$ & 167 \\
2 & 12.905 & 0.88 & 4-Decyl methylphosphonofluoridate & $\mathrm{C}_{11} \mathrm{H}_{24} \mathrm{FO}_{2} \mathrm{P}$ & 182 \\
3 & 14.574 & 2.49 & Dipentene diepox & $\mathrm{C}_{10} \mathrm{H}_{16} \mathrm{O}_{2}$ & 136 \\
4 & 15.727 & 3.23 & Arachidic acid methyl ester & $\mathrm{C}_{21} \mathrm{H}_{42} \mathrm{O}_{2}$ & 296 \\
5 & 17.08 & 3.05 & 1-Pentadecanecarboxylic acid & $\mathrm{C}_{16} \mathrm{H}_{32} \mathrm{O}_{2}$ & 314 \\
6 & 18.941 & 4.78 & Methyl (9E,12E)-9,12-octadecadienoate & $\mathrm{C}_{19} \mathrm{H}_{34} \mathrm{O}_{2}$ & 294 \\
7 & 19.00 & 7.89 & Methyl (10E)-10-octadecenoate & $\mathrm{C}_{19} \mathrm{H}_{36} \mathrm{O}_{2}$ & 296 \\
8 & 19.36 & 1.19 & Methyl arachisate (Kemester 2050) & $\mathrm{C}_{21} \mathrm{H}_{42} \mathrm{O}_{2}$ & 326 \\
9 & 20.17 & 24.99 & Z-9-Tetradecanol & $\mathrm{C}_{14} \mathrm{H}_{26} \mathrm{O}$ & 214 \\
10 & 21.07 & 4.99 & trans-13-Docosenoic acid & $\mathrm{C}_{22} \mathrm{H}_{42} \mathrm{O}_{2}$ & 338 \\
11 & 21.71 & 1.86 & Glycerin 1,3-distearate & $\mathrm{C}_{39} \mathrm{H}_{76} \mathrm{O}_{5}$ & 625 \\
12 & 22.74 & 2.10 & Dioctyl adipate & $\mathrm{C}_{22} \mathrm{H}_{42} \mathrm{O}_{4}$ & 370 \\
13 & 23.12 & 1.15 & Lineoleoyl chloride & $\mathrm{C}_{18} \mathrm{H}_{31} \mathrm{ClO}$ & 300 \\
14 & 23.58 & 9.12 & cis-Oleic acid & $\mathrm{C}_{18} \mathrm{H}_{34} \mathrm{O}_{2}$ & 282 \\
15 & 23.79 & 1.98 & Eicosanoic acid & $\mathrm{C}_{20} \mathrm{H}_{40} \mathrm{O}_{2}$ & 312 \\
16 & 24.31 & 18.99 & n-Octyl phthalate & $\mathrm{C}_{24} \mathrm{H}_{38} \mathrm{O}_{4}$ & 390 \\
17 & 25.38 & 1.12 & 13-Tetradecenal & $\mathrm{C}_{14} \mathrm{H}_{26} \mathrm{O}$ & 210
\end{tabular}

interpretation. Clotrimazole + TEO against C. albicans, ketoconazole + TEO against $A$. niger, terbinafine + TEO against C. albicans, clotrimazole + AVG against $C$. albicans, fluconazole $+\mathrm{TEO}$ against $A$. flavus and terbinafine + AVG against $C$. tropicalis (ATCC 66029) displayed synergistic properties. Other combinatory effects of AFC with TEO or AVG were indifferent without antagonism.

\section{Discussion}

Researchers across the board have responded to continuous increase of multiple antibiotic resistance by pathogenic fungal strains and thus, revealed that novel potential strategy to promote antifungal therapeutic is urgently needed to be explored [26]. In this study, the combinatory potential of AFCs with TEO or AVG was assessed. Terbinafine was efficient AFC against pathogenic fungi in vitro. Terbinafine is known as a broad spectrum antifungal agent, active against wide range of dermatophytes, moulds, yeasts and dimorphic fungi [27]. However, studies by Karri et al. [28] reported less activity of terbinafine against Candida albicans. Terbinafine was considered to have potency against dermatophytes but now, there is a rise to terbinafine resistance by pathogenic fungi [29].

The efficacy of AFCs (azole creams) such as clotrimazole, fluconazole, and ketoconazole against selected pathogenic fungi was observed, while fungi such as

Table 3 Zones of inhibition ( $\mathrm{mm}$ ) by AFCs, TEO and AVG against pathogenic fungi at $10.0 \mathrm{mg} / \mathrm{ml}$ of each tested agent

\begin{tabular}{|c|c|c|c|c|c|c|}
\hline Isolates & Clotrimazole & Fluconazole & Ketoconazole & Terbinafine & TEO & AVG \\
\hline Candida tropicalis (ATCC 66029) & $10.6 \pm 0.2^{a}$ & $8.0 \pm 0.0^{b}$ & $11.0 \pm 0.0^{\mathrm{a}}$ & $8.0 \pm 0.1^{b}$ & $10.0 \pm 0.1^{\mathrm{a}}$ & $8.3 \pm 0.0^{b}$ \\
\hline Candida albicans & $5.3 \pm 0.0^{c}$ & $7.0 \pm 0.6^{b}$ & $9.0 \pm 0.0^{\mathrm{a}}$ & $9.3 \pm 0.0^{\mathrm{a}}$ & $5.0 \pm 0.0^{c}$ & $9.7 \pm 0.1^{\text {a }}$ \\
\hline Penicillium notatum & $11.6 \pm 0.1^{\mathrm{a}}$ & $11.3 \pm 0.6^{a}$ & $7.0 \pm 0.3^{b}$ & $10.7 \pm 0.3^{a}$ & $10.0 \pm 0.3^{a}$ & $10.0 \pm 0.0^{\mathrm{a}}$ \\
\hline Aspergillus fumigatus & $8.0 \pm 0.0^{b}$ & $6.0 \pm 0.0^{c}$ & $5.0 \pm 0.0^{c}$ & $11.0 \pm 0.0^{a}$ & $9.2 \pm 0.0^{\mathrm{ab}}$ & $10.0 \pm 0.0^{a}$ \\
\hline Aspergillus niger & $11.0 \pm 0.2^{a}$ & $8.0 \pm 0.0^{c}$ & $7.3 \pm 0.1^{c}$ & $10.0 \pm 0.0^{\mathrm{ab}}$ & $8.3 \pm 0.0^{c}$ & $12.7 \pm 0.2^{a}$ \\
\hline Aspergillus flavus & $10.6 \pm 0.2^{b}$ & $9.0 \pm 0.5^{b c}$ & $6.0 \pm 0.0^{d}$ & $14.0 \pm 0.0^{a}$ & $11.0 \pm 0.0^{b}$ & $8.0 \pm 0.0^{c}$ \\
\hline Trichophyton rubrum & $5.0 \pm 0.0^{c}$ & $5.3 \pm 0.0^{c}$ & $10.3 \pm 0.1^{b}$ & $14.3 \pm 0.2^{a}$ & $10.3 \pm 0.2^{b}$ & $11.7 \pm 0.3^{b}$ \\
\hline Trichophyton violceum & $8.0 \pm 0.1^{b}$ & $6.0 \pm 0.0^{c}$ & $11.3 \pm 0.0^{a}$ & $10.6 \pm 0.3^{a}$ & $10.6 \pm 0.3^{a}$ & $8.7 \pm 0.1^{b}$ \\
\hline Trichophyton mentagrophytes & $8.3 \pm 0.0^{b}$ & $5.0 \pm 0.0^{d}$ & $8.0 \pm 0.0^{b}$ & $12.7 \pm 0.3^{a}$ & $7.9 \pm 0.0 \mathrm{bc}$ & $9.0 \pm 0.5^{b}$ \\
\hline
\end{tabular}

Value are mean \pm SD of replicates $(n=3)$. Values with the same superscript alphabet along row are not significantly different from each other when $P<0.05$ 
Table 4 Zones of inhibition (mm) displayed by combined AFCs with TEO or AVG against pathogenic fungi at $3.0 \mathrm{mg} / \mathrm{ml}$ of each tested agent

\begin{tabular}{|c|c|c|c|c|c|c|c|c|}
\hline Isolates & $\begin{array}{l}\text { Clotrimazole } \\
+ \text { TEO }\end{array}$ & $\begin{array}{l}\text { Fluconazole } \\
+ \text { TEO }\end{array}$ & $\begin{array}{l}\text { Ketoconazole } \\
+ \text { TEO }\end{array}$ & $\begin{array}{l}\text { Terbinafine } \\
+ \text { TEO }\end{array}$ & $\begin{array}{l}\text { Clotrimazole } \\
+ \text { AVG }\end{array}$ & $\begin{array}{l}\text { Fluconazole } \\
+ \text { AVG }\end{array}$ & $\begin{array}{l}\text { Ketoconazole } \\
+ \text { AVG }\end{array}$ & $\begin{array}{l}\text { Terbinafine } \\
+ \text { AVG }\end{array}$ \\
\hline $\begin{array}{l}\text { C. tropicalis (ATCC } \\
\text { 66029) }\end{array}$ & $9.6 \pm 0.2^{b c}$ & $8.0 \pm 0.0^{c}$ & $10.0 \pm 0.0^{a}$ & $12.0 \pm 0.3^{a}$ & $7.7 \pm 0.0^{c d}$ & $10.3 \pm 1.5^{a}$ & $7.3 \pm 0.1^{c d}$ & $11.3 \pm 1.2^{a}$ \\
\hline C. albicans & $10.6 \pm 0.2^{b}$ & $11.0 \pm 0.5^{b}$ & $9.0 \pm 0.0^{c}$ & $8.6 \pm 0.8^{c}$ & $9.0 \pm 1.0^{c}$ & $8.0 \pm 2.0^{c}$ & $7.0 \pm 0.0^{d}$ & $12.7 \pm 1.0^{a}$ \\
\hline $\begin{array}{l}\text { Penicillium } \\
\text { notatum }\end{array}$ & $10.7 \pm 0.6^{b}$ & $11.3 \pm 0.6^{b}$ & $7.7 \pm 0.3^{d}$ & $9.7 \pm 0.3^{c}$ & $9.0 \pm 1.0^{c}$ & $6.0 \pm 1.0^{e}$ & $8.0 \pm 1.0^{d}$ & $13.6 \pm 1.3^{a}$ \\
\hline A. fumigatus & $9.0 \pm 0.6^{b}$ & $8.0 \pm 0.0^{b}$ & $8.0 \pm 0.0^{b}$ & $8.0 \pm 0.0^{b}$ & $11.0 \pm 2.0^{a}$ & $11.0 \pm 1.0^{a}$ & $10.6 \pm 1.7^{a}$ & $10.7 \pm 0.5^{a}$ \\
\hline A. niger & $10.0 \pm 0.6^{a}$ & $8.0 \pm 0.0^{b}$ & $7.0 \pm 0.0^{b}$ & $7.0 \pm 0.0^{b}$ & $7.0 \pm 1.0^{b}$ & $7.7 \pm 0.5^{b}$ & $8.6 \pm 0.3^{b}$ & $11.3 \pm 0.3^{a}$ \\
\hline A. flavus & $9.6 \pm 0.2^{b}$ & $7.0 \pm 0.0^{c}$ & $9.0 \pm 0.5^{b}$ & $11.0 \pm 0.5^{a}$ & $10.0 \pm 1.0^{a}$ & $9.0 \pm 1.0^{b}$ & $7.3 \pm 0.3^{c}$ & $10.7 \pm 0.5^{a}$ \\
\hline T. rubrum & $6.0 \pm 0.5^{d}$ & $10.3 \pm 0.3^{b}$ & $11.0 \pm 0.5^{b}$ & $9.6 \pm 0.3^{b c}$ & $8.0 \pm 0.3^{c}$ & $10.7 \pm 1.3^{b}$ & $8.0 \pm 0.0^{c}$ & $13.7 \pm 0.3^{a}$ \\
\hline T. violceum & $10.0 \pm 0.6^{a}$ & $9.3 \pm 0.0^{a b}$ & $9.0 \pm 0.5^{a b}$ & $10.3 \pm 1.0^{a}$ & $10.0 \pm 0.0^{a}$ & $8.0 \pm 1.0^{b}$ & $11.3 \pm 0.5^{\mathrm{a}}$ & $10.0 \pm 0.0^{a}$ \\
\hline $\begin{array}{l}T . \\
\text { mentagrophytes }\end{array}$ & $8.0 \pm 0.5^{c d}$ & $9.0 \pm 0.5^{c}$ & $8.3 \pm 0.3^{c}$ & $7.6 \pm 0.3^{d}$ & $11.7 \pm 1.1^{b}$ & $10.0 \pm 2.0^{b}$ & $12.7 \pm 0.0^{a}$ & $13.7 \pm 0.8^{a}$ \\
\hline
\end{tabular}

Value are mean \pm SD of replicates $(n=3)$. Values with the same superscript alphabet along row are not significantly different from each other when $P<0.05$

Candida albicans, Trichophyton rubrum, T. mentagrophytes required higher concentration of AFCs before being inhibited. Shivamurthy et al. [30] reported that sertaconazole showed better anti-dermatophytic in clinical parameters than topical clotrimazole within a span of 3 weeks in the treatment of Tinea corporis. Sabatelli et al. [31] tested triazoles against wide number of clinically important pathogenic fungi $(19,000$ yeast and mould) and found out that, species of Candida and Aspergillus exhibited resistance to fluconazole, voriconazole, itraconazole and amphotericin B except posaconazole that was more efficient. Azole or triazole are commonly used antifungal agents that suppress fungi growth by inhibiting a key enzyme; lanosterol 14alpha demethylase, which occurs through the binding of the free nitrogen atom of the azole ring to the iron atom of the heme-group of the enzyme [32].

In this study, in vitro antifungal effectiveness of overthe-counter AFCs and their synergism with TEO or
AVG against pathogenic fungi of clinical sources was attributed to phytochemicals as well as bioactive ingredients in TEO and AVG. Phytochemicals are biologically active, naturally occurring chemical compounds in plants that promote human health and prevent diseases [33]. The presence of these biologically active phytochemicals (phenol, flavonoids, saponins, alkaloids, steroids, terpenoids, cardiac glycosides, anthraquinones and tannins) in studied extracts make them useful for some medicinal purposes such as antimicrobial against pathogenic microorganisms. Sawant and Godghate [34] reported that turmeric was one of the best source to obtain a variety of drugs due to its rich phytochemical constituents.

Bawankar et al. [35] reported the presence of hexadecanoic acid, 1-(phenylthioxomethyl) piperidine, 6-hydroxyhexane-3-1, octadecanoic acid, tricosane, 1octadecanol, stigmasterol, docosane in the ethanolic extract of A. vera. Hydroxybenzhydrazide was found

Table 5 Minimum inhibitory concentration $(\mathrm{mg} / \mathrm{ml})$ of AFCs, TEO and AVG against pathogenic fungi

\begin{tabular}{|c|c|c|c|c|c|c|}
\hline Isolates & Clotrimazole & Fluconazole & Ketoconazole & Terbinafine & TEO & AVG \\
\hline C. tropicalis (ATCC 66029) & 2.50 & 2.50 & 5.00 & 10.00 & 2.50 & 2.50 \\
\hline C. albicans & 10.00 & 5.00 & 5.00 & 10.00 & 10.00 & 5.00 \\
\hline P. notatum & 2.50 & 2.50 & 5.00 & 2.50 & 5.00 & 2.50 \\
\hline A. fumigatus & 5.00 & 5.00 & 10.00 & 2.50 & 5.00 & 5.00 \\
\hline A. niger & 5.00 & 5.00 & 10.00 & 2.50 & 10.00 & 2.50 \\
\hline A. flavus & 2.50 & 5.00 & 10.00 & 1.25 & 5.00 & 5.00 \\
\hline T. rubrum & 10.00 & 10.00 & 5.00 & 2.50 & 5.00 & 2.50 \\
\hline T. violceum & 10.00 & 10.00 & 5.00 & 1.25 & 5.00 & 1.25 \\
\hline T. mentagrophytes & 5.00 & 10.00 & 5.00 & 5.00 & 5.00 & 2.50 \\
\hline
\end{tabular}


Table 6 Minimum inhibitory concentration $(\mathrm{mg} / \mathrm{ml})$ of combined AFCs with TEO or AVG against pathogenic fungi

\begin{tabular}{|c|c|c|c|c|c|c|c|c|}
\hline Isolates & $\begin{array}{l}\text { Clotrimazole }+ \\
\text { TEO }\end{array}$ & $\begin{array}{l}\text { Fluconazole + } \\
\text { TEO }\end{array}$ & $\begin{array}{l}\text { Ketoconazole + } \\
\text { TEO }\end{array}$ & $\begin{array}{l}\text { Terbinafine }+ \\
\text { TEO }\end{array}$ & $\begin{array}{l}\text { Clotrimazole }+ \\
\text { AVG }\end{array}$ & $\begin{array}{l}\text { Fluconazole + } \\
\text { AVG }\end{array}$ & $\begin{array}{l}\text { Ketoconazole + } \\
\text { AVG }\end{array}$ & $\begin{array}{l}\text { Terbinafine }+ \\
\text { AVG }\end{array}$ \\
\hline $\begin{array}{l}\text { C. tropicalis (ATCC } \\
66029 \text { ) }\end{array}$ & 1.50 & 1.00 & 2.00 & 3.00 & 1.00 & 1.50 & 1.00 & 1.00 \\
\hline C. albicans & 2.50 & 3.00 & 2.00 & 2.00 & 1.00 & 2.50 & 2.00 & 2.00 \\
\hline P. notatum & 2.00 & 2.00 & 1.50 & 1.00 & 1.00 & 1.00 & 1.50 & 1.50 \\
\hline A. fumigatus & 2.50 & 2.50 & 3.00 & 1.00 & 1.50 & 1.50 & 2.50 & 1.00 \\
\hline A. niger & 2.00 & 3.00 & 2.50 & 1.50 & 1.00 & 2.50 & 1.50 & 1.50 \\
\hline A. flavus & 2.00 & 2.50 & 2.50 & 1.50 & 1.50 & 1.00 & 2.00 & 1.50 \\
\hline T. rubrum & 3.00 & 3.00 & 1.50 & 2.50 & 1.50 & 1.50 & 2.50 & 2.50 \\
\hline T. violceum & 2.50 & 2.00 & 2.50 & 1.00 & 1.00 & 2.00 & 1.50 & 2.00 \\
\hline T. mentagrophytes & 1.50 & 2.50 & 3.00 & 2.00 & 2.00 & 2.00 & 2.00 & 1.50 \\
\hline
\end{tabular}

in AVG. It is a hydroxylated phenolic compound with strong and moderate antimicrobial activity [36]. Hydroxylated phenolic compounds like pyrocatechol are known to be toxic to microorganisms [37]. The toxicity of phenolic compounds to microorganisms are believed to be related to the number of hydroxyl groups, which inhibit microbial growth by cell membrane disruption and protein denaturation [38].
Alpha-phellandrene, $\alpha$-pinene, myrcene, linalol, geraniol, ar-turmerone, turmerone, $\alpha$-curcumene, zingiberene, turmerones, curcuminiods, geraniol acetate beta-sesquiphellandrene, (2E,6E)-farnesol, camphene, tricyclen cineole were major bioactive compounds as aromatic compounds in EOs with dynamic antimicrobial features [39, 40]. Alpha-phellandrene is a terpene-derivative metabolite, which is mostly found

Table 7 Fractional inhibitory concentration (FIC) and FIC indices (FICi)

\begin{tabular}{|c|c|c|c|c|c|c|c|c|c|}
\hline FIC ${ }^{\mathrm{a}} \mathrm{FICi} /$ interpretation & C. tropicalis (ATCC 66029) & C. albicans & P. notatum & A. fumigatus & A. niger & A. flavus & T. rubrum & T. violceum & T. mentagrophytes \\
\hline Clotrimazole & 0.60 & 0.25 & 0.80 & 0.50 & 0.40 & 0.80 & 0.30 & 0.25 & 0.30 \\
\hline TEO & 0.60 & 0.25 & 0.40 & 0.50 & 0.20 & 0.40 & 0.60 & 0.50 & 0.30 \\
\hline $\mathrm{FICi}$ & $1.20 /$ ind & $0.50 /$ syn & $1.20 /$ ind & $1.00 /$ ind & $0.60 /$ ind & $1.20 /$ ind & $0.90 /$ ind & $0.75 /$ ind & $0.60 /$ ind \\
\hline Fluconazole & 0.40 & 0.60 & 0.80 & 0.50 & 0.60 & 0.50 & 0.30 & 0.20 & 0.25 \\
\hline TEO & 0.40 & 0.30 & 0.40 & 0.50 & 0.30 & 0.50 & 0.60 & 0.40 & 0.50 \\
\hline $\mathrm{FICi}$ & $0.80 /$ ind & $0.90 /$ ind & $1.20 /$ ind & $1.00 /$ ind & $0.90 /$ ind & $1.00 /$ ind & $0.90 /$ ind & $0.60 /$ ind & $0.75 /$ ind \\
\hline Ketoconazole & 0.40 & 0.40 & 0.30 & 0.30 & 0.25 & 0.25 & 0.30 & 0.50 & 0.60 \\
\hline TEO & 0.80 & 0.20 & 0.30 & 0.60 & 0.25 & 0.50 & 0.30 & 0.50 & 0.60 \\
\hline $\mathrm{FICi}$ & 1.20/ind & $0.60 /$ ind & $0.60 /$ ind & $0.90 /$ ind & $0.50 /$ syn & $0.75 /$ ind & $0.60 /$ ind & $1.00 /$ ind & $1.20 /$ ind \\
\hline Terbinafine & 0.30 & 0.20 & 0.40 & 0.40 & 0.60 & 1.20 & 1.00 & 0.80 & 0.40 \\
\hline TEO & 1.20 & 0.20 & 0.20 & 0.20 & 0.15 & 0.30 & 0.50 & 0.20 & 0.40 \\
\hline $\mathrm{FICi}$ & $1.50 /$ ind & $0.40 /$ syn & $0.60 /$ ind & $0.60 /$ ind & $0.75 /$ ind & 1.50/ind & $1.50 /$ ind & $1.00 /$ ind & $0.80 /$ ind \\
\hline Clotrimazole & 0.40 & 0.10 & 0.40 & 0.30 & 0.20 & 0.60 & 0.15 & 0.10 & 0.40 \\
\hline AVG & 0.40 & 0.20 & 0.40 & 0.30 & 0.40 & 0.30 & 0.60 & 0.80 & 0.80 \\
\hline $\mathrm{FICi}$ & $0.80 /$ ind & $0.30 /$ syn & $0.80 /$ ind & $0.60 /$ ind & $0.60 /$ ind & $0.90 /$ ind & $0.75 /$ ind & $0.90 /$ ind & $1.20 /$ ind \\
\hline Fluconazole & 0.60 & 0.50 & 0.40 & 0.30 & 0.50 & 0.20 & 0.15 & 0.20 & 0.20 \\
\hline AVG & 0.60 & 0.50 & 0.40 & 0.30 & 1.00 & 0.20 & 0.60 & 1.60 & 0.80 \\
\hline $\mathrm{FICi}$ & $1.20 /$ ind & $1.00 /$ ind & $0.80 /$ ind & $0.60 /$ ind & $1.50 /$ ind & $0.40 /$ syn & $0.75 /$ ind & $1.80 /$ ind & $1.00 /$ ind \\
\hline Ketoconazole & 0.20 & 0.40 & 0.30 & 0.25 & 0.15 & 0.20 & 0.50 & 0.30 & 0.40 \\
\hline AVG & 0.40 & 0.40 & 0.60 & 0.50 & 0.60 & 0.40 & 1.00 & 1.20 & 0.80 \\
\hline $\mathrm{FICi}$ & $0.60 /$ ind & $0.80 /$ ind & $0.90 /$ ind & $0.75 /$ ind & $0.75 /$ ind & $0.60 /$ ind & $1.50 /$ ind & $1.50 /$ ind & $1.20 /$ ind \\
\hline Terbinafine & 0.10 & 0.20 & 0.60 & 0.40 & 0.60 & 1.20 & 1.00 & 1.60 & 0.30 \\
\hline AVG & 0.40 & 0.40 & 0.60 & 0.20 & 0.60 & 0.30 & 1.00 & 1.60 & 0.60 \\
\hline $\mathrm{FICi}$ & $0.50 /$ syn & $0.60 /$ ind & $1.20 /$ ind & $0.60 /$ ind & $1.20 /$ ind & $1.50 /$ ind & $2.00 /$ ind & $3.20 /$ ind & $0.90 /$ ind \\
\hline
\end{tabular}

syn Synergetic, ind Indifferent

${ }^{a}$ Bold indicates Fractional Inhibitory Concentration index (FICi) / their interpretation 
in volatile oils and plays a role of an antimicrobial agent [41]. The presence of $\alpha$-phellandrene in this study correlates with the findings of Mukesi et al. [42] who examined the bioactivity of commercial antimicrobials, EO and ethanolic extracts of Olea europaea. Another major component found in TEO is 2 -carene. It is a bicyclic monoterpene that occurs in several EOs with a sweet and pungent odour. Carene and its derivatives are of modest relevance in the perfume industry [43], hence, its presence in TEO could contributed to spicy aromatic scent. Farnesene, a volatile compound, which was identified in TEO is known to be responsible for the characteristic taste and flavour of turmeric related to peppermint [44].

TEO exhibited pronounce inhibition against Candida albicans, Penicillium notatum, species of Aspergillus and Trichophyton. Ferreira et al. [45] attributed the inhibition of $A$. flavus growth at $0.10 \%$, reduction of their viable spores at $0.10 \%$ and complete inhibition at $0.50 \%$ to arturmerone $\alpha$-turmerone and $\beta$-turmerone, being a major component of EO of C. longa. EOs components act as antifungal agents (fungistatic and fungicidal) against fungi by deactivating or disrupting the structure and function of membranes or organelles of fungal cell and/ or inhibiting the nuclear material or protein synthesis inactivation, inhibition of intracellular and extracellular enzymes [38].

The antagonistic activity of $A$. vera against bacteria, fungi and viruses has been expounded by some studies [46-48]. The antifungal potential of AVG against tested pathogenic fungi corresponds to the findings of Nidiry et al. [49] who reported antifungal property of bioactive constituents; aloin and aloe-emodin in A. vera against Colletotrichum gloeosporides and Cladosporium сисиmerinum. The inhibitory efficiency of AVG corroborates to the findings of Khwakhali and Shrivatava [50] who reported the effectiveness of $A$. vera against pathogenic Aspergillus spp., while Al-Snafi [51] obtained effective treatment (70\% growth inhibition) of guinea pig infected with T. mentagrophytes. AVG possessed broad antifungal activities against the tested fungi. Findings of Bawankar et al. [35], Saks and Barkai-Golan [52], and Yebpella et al. [53] have reported antifungal activity of AVG against the growth of Penicillium spp., Botrytis cineria, Alternaria alternate, Aspergillus spp. and Candida albicans at varying concentrations. The antimicrobial potential of $A$. vera could be attributed to anthraquinone and pyrocatechol in the gel of leaves, which are toxic to microorganisms by blocking their ribosomal A site [54]. A. vera is one of the most important traditional folk and alternative medicine often used for the treatment of infectious diseases with no side effects [55].

In this study, it was observed that the combination of plant extracts; TEO or AVG with AFC was effective against all the tested fungi. Jankasem et al. [56] revealed that turmeric oil displayed better anti-dermatophytic activity with the MICs of $1.56-6.25 \mu \mathrm{g} / \mathrm{mL}$ when compared to $3.90-7.81 \mu \mathrm{g} / \mathrm{mL}$ of ketoconazole. Shin and Lim [57] revealed that antifungal potential of ketoconazole was significantly improved against Trichophyton schoenleinii, T. erinacei and T. soudanense when combined with EO of Pelargonium graveolens. The FICi obtained for oils of thyme, cinnamon, clove and eucalyptus combined with amphotericin B against $C$. albicans and $A$. niger suggested that synergistic of antifungal drugs with herbs (oil or and extracts) yielded efficacious dose for the treatment of fungal infections and thus, minimizing its side effects [58]. Most EO of Styrax tonkinensis, Lavandula angustifolia, Melaleuca alternifolia, Rosmarinus officinalis, and Pelargonium graveolens and its fractional components; geraniol and citronellol exhibited additive effect when combined with amphotericin B and with ketoconazole against Aspergillus spp., which resulted to FICi ranged from 0.52 to 1.00 [53]. In the findings of Scalas et al. [40], EOs of Origanum vulgare (oregano), Pinus sylvestris (pine), and Thymus vulgaris (thyme red) and their components ( $\alpha$-pinene, carvacrol, thymol) exhibited good antifungal activity against Cryptococcus neoformans strains compared to fluconazole, itraconazole, and voriconazole, and thus, revealed the synergistic and additive for EO and azole (itraconazole) combination. Potential synergistic combination between two or more antimicrobial agents help in reducing resistant mutants, exhibit more antimicrobial action, toxicity against pathogens and thus, serve as effective alternative traditional medicine for the treatment of various fungal infections [59-61]. The use of EOs aromatic compounds and plant extracts in formulation of topical AFCs need to be embraced to achieve optimal antifungal activity with no side effects. The availability of natural products (EOs or plant extracts) and development of combined antimicrobial agents are often an optional therapy for dermatological infections [62].

\section{Conclusion}

AFCs, TEO and AVG inhibited the growth of all tested pathogenic fungi with varying degrees of zones of inhibition. Combinatory action of AFCs with TEO or AVG did not slow down their bioactivity against tested fungi. This indicated that bioactive compounds in plant extracts can complement the activity of AFCs to improve their clinical efficacy. The antifungal properties of TEO or AVG combined with different AFCs established their importance in phytomedicine and cosmeceutical. The combination of AFCs with plant extracts will serve as alternative medicine in treating or combating many infectious fungal diseases such as dermatophytosis, which had been a widespread disease. The bioactive ingredients 
in plant extracts could argument the formulation of body and hair creams (cosmetics) to treat resistant pathogenic fungi within short time with no side effects.

\section{Acknowledgements}

Not applicable.

\section{Authors' contributions}

OCO and BJA designed the research work. OCO, AEO, OBA, OMA and OAT carried out the experimental study. OCO and BJA supervised the work. OCO and OBA drafted the manuscript. All authors revised the manuscript. Authors read and approved the final manuscript.

\section{Funding}

Not applicable.

\section{Availability of data and materials}

The data used or analysed during the current study are available.

\section{Ethics approval and consent to participate}

Not applicable.

\section{Consent for publication}

Not applicable.

\section{Competing interests}

Authors declared no competing interests.

\section{Author details}

'Biotechnology Unit, Department of Biological Sciences, Kings University, PMB 555, Odeomu, Nigeria. ${ }^{2}$ Department of Microbiology, The Federal University of Technology, PMB 704, Akure, Nigeria. ${ }^{3}$ Microbiology Unit, Department of Biological Sciences, Kings University, PMB 555, Odeomu, Nigeria.

\section{Received: 7 September 2020 Accepted: 4 January 2021}

\section{Published online: 28 January 2021}

\section{References}

1. Warnock DW. Fungal diseases: an evolving public health challenge. J Med Mycol. 2006;44(8):697-705

2. Almeida F, Rodrigues ML, Coelho $\mathrm{C}$. The still underestimated problem of fungal diseases worldwide. Front Microbiol. 2019;10:214. https://doi.org/10 3389/fmicb.2019.00214

3. Homei A, Worboys M. Candida: a disease of antibiotics. In: Fungal disease in Britain and the United States 1850-2000. Science, Technology and Medicine in Modern History. London: Palgrave Macmillan; 2013.

4. Arif T, Bhosale JD, Kumar N, Mandal TK, Bendre RS, Lavekar GS, Dabur R. Natural products - antifungal agents derived from plants. J Asian Nat Prod Res. 2019;11(7):621-38.

5. Scorzoni L, de Paula e Silva ACA, Marcos CM, Assato PA, de Melo WCM, de Oliveira HC, Costa-Orlandi CB, Mendes-Giannini MJS, Fusco-Almeida AM. Antifungal therapy: new advances in the understanding and treatment of mycosis. Front Microbiol. 2017:8:36.

6. Kumar L, Verma S, Bhardwaj A, Vaidya S, Vaidya B. Eradication of superficial fungal infections by conventional and novel approaches: a comprehensive review. Artif Cells Nanomed Biotechnol. 2014;42(1):32-46.

7. Sousa F, Ferreira D, Reis S, Costa P. Current insights on antifungal therapy: novel nanotechnology approaches for drug delivery systems and new drugs from natural sources. Pharmaceuticals (Basel). 2020;13:248-77.

8. Spitzer M, Robbins N, Wright GD. Combinatorial strategies for combating invasive fungal infections. Virulence. 2017;8(2):169-85.

9. Vengurlekar S, Sharma R, Trivedi P. Efficacy of some natural compounds as antifungal agents. Pharm Rev. 2012;6(12):91-9.

10. InformedHealth.org [Internet]. Cologne: Institute for Quality and Efficiency in Health Care (IQWiG); 2006-. Vaginal yeast infections (thrush): What helps? 2019 Jun 19. Available from: https://www.ncbi.nlm.nih.gov/books/NBK54321 $9 \%$

11. Zhou X, Seto SW, Chang D, Kiat H, Razmovski-Naumovski V, Chan K, Bensoussan A. Synergistic effects of Chinese herbal medicine: a comprehensive review of methodology and current research. Front Pharmacol. 2016;7:201. https://doi.org/10.3389/fphar.2016.00201.

12. Mukherjee PK, Sheehan DJ, Hitchcock CA, Ghannoum MA. Combination treatment of invasive fungal infections. Clin Microbiol Rev. 2005;18(1):16394.

13. Singh R, Dubey AK. Endophytic actinomycetes as emerging source for therapeutic compounds. Indo Global J Pharm Sci. 2015;5:106-16.

14. Sharifi-Rad J, Rayess YE, Rizk AA, Sadaka C, Zgheib R, Zam W, Sestito S, et al. Turmeric and its major compound Curcumin on health: bioactive effects and safety profiles for food, pharmaceutical, biotechnological and medicinal applications. Front Pharmacol. 2020;11:01021. https://doi.org/10.3389/fphar. 2020.01021.

15. Liu C, Cui Y, Pi F, Cheng Y, Guo Y, Qian H. Extraction, purification, structural characteristics, biological activities and pharmacological applications of Acemannan, a polysaccharide from Aloe vera: a review. Molecules. 2019; 24(8):1554. https://doi.org/10.3390/molecules24081554.

16. Bawankar R, Pooja S, Babu S. Bioactive compounds and medicinal properties of Aloe vera L.: an update. J Plant Sci. 2014;3:102-7.

17. Singh $Y D$, Jena $B$, Ningthoujam $R$, et al. Potential bioactive molecules from natural products to combat against coronavirus. Adv Tradit Med. 2020. https://doi.org/10.1007/s13596-020-00496-w.

18. Seema S, Veena $U$, Bhatt RP. Inhibitory effect of essential oils against Trichosporon ovoides causing piedra hair infection. Braz J Microbiol. 2012;12: 1347-54.

19. Sofowora A. Medicinal plants and traditional medicine in Africa. Ibadan: Spectrum Books; 1993.

20. Harborne J. Phytochemical methods: a guide to modern techniques of plant analysis. 3rd ed. London: Chapman and Hill; 1998.

21. Trease GE, Evans MC. Pharmacognosy. 14th ed. New Delhi: Elsevier; 2005.

22. Soladoye MO, Chukwuma EC. Quantitative phytochemical profile of the leaves of Cissus populnea Guill. \& Perr. (Vitaceae) - an important medicinal plant in central Nigeria. Arch Appl Sci Res. 2012;4(1):200-6.

23. Clinical and Laboratory Standards Institute (CLSI). Reference method for broth dilution antifungal susceptibility testing of filamentous fungi. 3rd ed. Wayne: CLSI supplement M38 Clinical and Laboratory Standards Institute 950; 2017

24. Clinical and Laboratory Standards Institute (CLSI). Performance standards for antifungal susceptibility testing of of filamentous fungi. 1st ed. Wayne: CLSI supplement M61 Clinical and Laboratory Standards Institute 950; 2017.

25. Odds FC. Synergy, antagonism, and what the chequerboard puts between them. J Antimicrob Chemother. 2003;52(1):1. https://doi.org/10.1093/jac/ dkg301.

26. Chen X, Ren B, Chen M, Liu MX, Ren W, Wang QX, Zhang LX, Yan GY. ASDC D: antifungal synergistic drug combination database. PLoS One. 2014;9(1): 86499.

27. Lam P, Stanton HLK, Kenneth KHL, Lam KH, Desmond KPH, Wong WY, Bian Z, Gambari R, Chung HC. Sensitization of Candida albicans to terbinafine by berberine and berberrubine. Biomed Rep. 2016;4(4):449-52.

28. Karri W, Raman SK, Kuppusamy G, Sanapalli BKR, Wadhwani A, Patel V, Malayandi R. In vitro antifungal activity of a novel allylamine antifungal nanoemulsion gel. J Nanosci Curr Res. 2018;3(1):1-5.

29. Babu PR, Pravin AJS, Deshmukh G, Dhoot D, Samant A, Kotak B. Efficacy and safety of terbinafine $500 \mathrm{mg}$ once daily in patients with dermatophytosis. Indian J Dermatol. 2017;62(4):395-9.

30. Shivamurthy RP, Reddy SG, Kallappa R, Somashekar SA, Patil D, Patil UN. Comparison of topical anti- fungal agents sertaconazole and clotrimazole in the treatment of Tinea corporis- an observational study. J Clin Diagn Res. 2014;8(9):9-12.

31. Sabatelli F, Patel R, Mann PA, Mendrick CA, Norris CC, Hare R, Loebenberg D, Black TA, McNicholas PM. In vitro activities of posaconazole, fluconazole, itraconazole, voriconazole, and amphotericin B against a large collection of clinically important molds and yeasts. Antimicrob Agents Chemother. 2006;50(6):2009-15.

32. Vandeputte $\mathrm{P}$, Ferrari $\mathrm{S}$, Coste AT. Antifungal resistance and new strategies to control fungal infections. Intern J Microbiol. 2012;ID713687:1-26.

33. Saini A, Singh B, Suttee A, Verma S, Garg LK, Thakur S. A review on phytoconstituents: the potent synergistic approach in antimicrobial formulations. J Pharm Res. 2018;12(2):151-9.

34. Sawant RS, Godghate AG. Qualitative phytochemical screening of rhizomes of Curcuma longa Linn. Intern J Sci Environ Technol. 2013;2(4):634-41.

35. Bawankar R, Deepti VC, Singh P, Subashkumar R, Vivekanandhan G, Babu S. Evaluation of bioactive potential of an Aloe vera sterol extract. Phytother Res. 2013;27(6):864-8. 
36. Nurkenov OA, Satpaeva B, Kulakov IV, Akhmetova SB, Zhaugasheva SK. Synthesis and antimicrobial activity of 0 - and p- hydroxybenzoic acid thiosemicarbazides. Russian J Gen Chem. 2012;82(4):668-71.

37. Lawrence $R$, Tripathi $P$, Jeyakumar E. Isolation, purification and evaluation of antibacterial agents from Aloe vera. Braz J Microbiol. 2009;40(4):906-15.

38. Nazzaro F, Fratianni F, Coppola R, Feo V. Essential oils and antifungal activity. Pharmaceuticals (Basel). 2017;10(4):86.

39. Chouhan S, Sharma K, Guleria S. Antimicrobial activity of some essential oilspresent status and future perspectives. Medicines. 2017;4(3):58.

40. Scalas D, Mandras N, Roana J, Tardugno R, Cuffini AM, Ghisetti V, Benvenuti S, Tullio V. Use of Pinus sylvestris L. (Pinaceae), Origanum vulgare L. (Lamiaceae), and Thymus vulgaris L. (Lamiaceae) essential oils and their main components to enhance itraconazole activity against azole susceptible/notsusceptible Cryptococcus neoformans strains. BMC Compl Altern Med. 2018; 18(1):143. https://doi.org/10.1186/s12906-018-2219-4.

41. İşcan G, Kirimer N, Demirci F, Demirci B, Noma Y, Başer KH. Biotransformation of (-)-(R)-a-phellandrene: antimicrobial activity of its major metabolite. Chem Biodivers. 2012;9(8):1525-32.

42. Mukesi M, Iweriebor BC, Obi LC, Uwodo UU, Moyo SR, Okoh Al. The activity of commercial antimicrobials, and essential oils and ethanolic extracts of Olea europaea on Streptococcus agalactiae isolated from pregnant women. BMC Complement Altern Med. 2019;19:34.

43. Zviely M, Hong C. Hydrocarbons: significance in the flavor and fragrance industries. Perfumer Flavorist Chem. 2019;34:1-9.

44. Kim JH, Cha JY, Shin TS, Chun SS. Volatile flavor components of blended tea with fermented tea and herbs. Preven Nutr Food Sci. 2018;23(3):245-53.

45. Ferreira FD, Mossini SAG, Ferreira FMD, Arrotéia CC, da Costa CL, Nakamura CV, Junior MM. The inhibitory effects of Curcuma longa L. essential oil and Curcumin on Aspergillus flavus link growth and morphology. Sci World J. 2013;ID 343804:1-6.

46. Athiban PP, Borthakur BJ, Ganesan S, Swathika B. Evaluation of antimicrobial efficacy of Aloe vera and its effectiveness in decontaminating gutta percha cones. JCD. 2012;15(3):246-8. https://doi.org/10.4103/0972-0707.9794.

47. Rezazadeh F, Moshaverinia M, Motamedifar M, Alyaseri M. Assessment of anti HSV-1 activity of Aloe vera gel extract: an in vitro study. J Dent (Shiraz). 2016;17(1):49-54.

48. Saniasiaya J, Salim R, Mohamad I, Harun A. Antifungal effect of Malaysian Aloe vera leaf extract on selected fungal species of pathogenic Otomycosis species in in vitro culture medium. Oman Med J. 2017;32(1):41-6. https:// doi.org/10.5001/omj.2017.08.

49. Nidiry ESJ, Ganeshan G, Lokesha AN. Antifungal activity of some extractives and constituents of Aloe vera. Res J Med Plant. 2011;5:196-200.

50. Khwakhali US and Shrivatava VP. Antifungal activity of Aloe vera extract against pathogenic species of Aspergillus isolated from Kathmandu, Nepal. 6th Advances against Aspergillosis, Madrid, Spain 27, February-1 March, 2014. http://www.AAA2014.org.

51. Al-Snafi AE. The pharmacological importance of Aloe vera- a review. Intern J Phytopharm Res. 2015;6(1):28-33.

52. Saks Y, Barkai-Golan R. Aloe vera activity against plant pathogenic fungi. Postharvest Biol Technol. 1995;6:159-65.

53. Yebpella GG, Hammuel C, Adeyemi HMM, Magomya AM, Agbaji AS, Shallangwa GA. Phytochemical screening and a comparative study of antibacterial activity of Aloe vera green rind, gel and leaf pulp extracts. Int Res J Microbiol. 2011;2(10):382-6.

54. Radha MH, Laxmipriya NP. Evaluation of biological properties and clinical effectiveness of Aloe vera: a systemic review. J Tradit Complement Med. 2015;5:21-6.

55. Laxminarain M. Traditional phytomedicinal systems, scientific validations and current popularity as nutraceuticals. Intern J Trad Nat Med. 2013;2(1):27-75.

56. Jankasem M, Wuthi-udomlert M, Gritsanapan W. Antidermatophytic properties of Ar-turmerone, turmeric oil, and Curcuma longa preparations. ISRN Dermatol. 2013;1-3:250597.

57. Shin S, Lim S. Antifungal effects of herbal essential oils alone and in combination with ketoconazole against Trichophyton spp. J Appl Microbiol. 2004:97:1289-96.

58. El-Ahmady S, El-Shazly M, Milad R. The synergetic efficacy of the combination of amphotericin B and certain essential oils against selected fungal clinical isolates. J Appl Pharm Sci. 2013;3(4):26-30.

59. Shin S. Anti-Aspergillus activities of plant essential oils and their combination effects with ketoconazole or amphotericin B. Arch Pharm Res. 2013;26:389

60. Duarte A, Ferreira S, Silva F, et al. Synergistic activity of coriander oil and conventional antibiotics against Acinetobacter baumannii. Phytomedicine. 2012;19:236-8.
61. Cheesman MJ, llanko A, Blonk B, Cock IE. Developing new antimicrobial therapies: are synergistic combinations of plant extracts/compounds with conventional antibiotics the solution? Pharmacogn Rev. 2017;11(22):57-72.

62. Orchard A, van Vuuren S. Commercial essential oils as potential antimicrobials to treat skin diseases. Evid Based Complement Alternat Med. 2017:ID 4517971 1-92

\section{Publisher's Note}

Springer Nature remains neutral with regard to jurisdictional claims in published maps and institutional affiliations.
Ready to submit your research? Choose BMC and benefit from:

- fast, convenient online submission

- thorough peer review by experienced researchers in your field

- rapid publication on acceptance

- support for research data, including large and complex data types

- gold Open Access which fosters wider collaboration and increased citations

- maximum visibility for your research: over $100 \mathrm{M}$ website views per year

At BMC, research is always in progress.

Learn more biomedcentral.com/submissions 